M. A. Hussein et al., Application of the rock mass classification systems to pillar design in longwall mining forabu-tartur longwall phosphate mining conditions, pp. 2012 - 2020

\title{
APPLICATION OF THE ROCK MASS CLASSIFICATION SYSTEMS TO PILLAR DESIGN IN LONGWALL MINING FOR ABU-TARTUR LONGWALL PHOSPHATE MINING CONDITIONS
}

\author{
M. A. Hussein *, A. R. Ibrahim, S.S. Imbaby \\ Staff in Mining and Metallurgical Eng. Depart. Faculty of Engineering, Assiut University, Egypt
}

Received 18 July 2013; accepted 14 September 2013

\begin{abstract}
Pillars are designed to ensure regional stability or local support in stopes and along drifts, or to yield under a measure of control. In all cases, the strength of the material and the variations in strength must be known both for the pillar and for the roof and floor. The stability in longwall faces depends mainly on the interaction between the roof strata, face support, roadway support and dimensions of pillars. The main aim of this paper is to apply rock mass classification systems to longwall pillar design at Abu-Tartur mining area. The pillar load is estimated taking into account the physical and mechanical properties of phosphate deposit and roof rock, panel width, mining height, depth below surface.

Two methods from classification systems are used in calculation pillars stress and strength to pillars design namely Geological Strength Index (GSI) and Rock Mass Rating (RMR) systems. GSI values for immediate, main roof rocks and phosphate ores are determined from geological conditions, as lithology, structure of the interlocking of rock blocks and the conditions of the surfaces between these blocks. RMR value can be determined by correlation it with GSI system. The pillar widths calculated by applying rock mass classifications (GSI\& RMR) are 49m and $64 \mathrm{~m}$ at a factor of safety 2 and panel width $100 \mathrm{~m}$ with extraction ratios of 70 and $64 \%$ respectively.

The data used in calculations are collected from geological reports of the company and from laboratory tests of phosphate ores and shale rocks in the roof.
\end{abstract}

Keywords: Rock Mass Classification (RMC) - Geological Strength Index (GSI) - Rock Mass Rating (RMR) -Abu-Tartur longwall phosphate mine - Pillar width.

\section{Introduction}

Rock mass classification systems have emerged as a powerful tool which can be used for assessing ground conditions and determining support requirements in underground mines [1]. Studies of pillar performance and strength in phosphate mines highlighted the need for pillar design guidelines that specifically address pillar stability in Abu-Tartur phosphate mines. At present, pillar dimensions are either based on rock mechanics science or on strength equations that were developed for metal or non-metal mines. This paper presents a pillar design based on rock mass classification systems that will assist in the design of safe pillar action in Abu-Tartur longwall phosphate mines.

There are many empirical methods to determine pillar designs each of these methods "classic" pillar design formulas consisted of three steps [2]:

a) Estimating the pillar load using tributary area theory

b) Estimating the pillar strength using a pillar strength formula

* Corresponding author.

Emaill address: mossad_ali2000@yahoo.com 
M. A. Hussein et al., Application of the rock mass classification systems to pillar design in longwall mining forabu-tartur longwall phosphate mining conditions, pp. 2012 - 2020

c) Calculating the pillar safety factor

Two methods from classification systems are used in calculation of pillars stress and strength to design pillars namely GSI and RMR systems. GSI values for immediate, main roof rocks and phosphate ores are determined from geological conditions, as lithology, structure of the interlocking of rock blocks and the conditions of the surfaces between these blocks $[3,4]$. RMR value can be determined by correlation it with GSI system [5].

The methodology used in this paper for the development of pillar design guidelines is based on the application of the rock mass classification systems to assess the optimum pillar dimensions in Abu-Tartur longwall mines. The significant variables which are taken into consideration can be grouped as flows:

a) Uniaxial compressive strength of phosphate ore (pillar)

b) Uniaxial compressive strength of papery clays (roof)

c) Face length (panel width)

d) Mining height (pillar height)

e) Depth below the surface

f) Specific weight of overburden rocks

The data used in calculations are collected from geological reports of the company and from laboratory tests of phosphate ores and shale rocks in the roof.

\section{Empirical Approach to Pillar Design}

When pillar strength is estimated, both size and shape effects must be considered. The size effect related to the presence of discontinuities within ore mass. Therefore rock mass strength is less than strength of intact laboratory sized samples. The shape effect describes the increase in the strength of the pillar when the width $\left(\mathrm{W}_{\mathrm{p}}\right)$ to height $(\mathrm{h})$ ratio increases. This is due to the increase in confining pressure within the pillar [6].

\section{Pillar Strength}

Pillar strength can be defined as the maximum resistance of a pillar to axial compression [7]. In flat lying deposits, pillar compression is caused by the weight of the overlying rock mass. Empirical evidence suggests that pillar strength is related to both its volume and its shape. Numerous equations have been developed that can be used to estimate the strength of pillars in coal and hard rock mines, and have been reviewed and summarized in the literature $[5,8,9,10,11]$. These equations are generally empirically developed and are only applicable for conditions similar to those under which they were developed. More recently, numerical model analyses combined with laboratory testing and field monitoring have contributed to the understanding of failure mechanisms and pillar strength [8].

$\sigma_{s}=k \frac{W_{P}^{\alpha}}{h^{\beta}}$

A pillar strength $\sigma_{\mathrm{s}}$ equation that captures both the pillar shape and volume effect is a power equation of the following form, where $\mathrm{k}$ is a parameter related to the rock strength, $\mathrm{W}_{\mathrm{p}}$ and $\mathrm{h}$ are the pillar width and height and $\alpha$ and $\beta$ are parameters related to the geomechanical conditions of the rock mass and different empirical equations are given in Table (1) [8.12].

Journal of Engineering Sciences, Assiut University, Faculty of Engineering, Vol. 41, No. 5, September, 2013, E-mail address: jes@aun.edu.eg 
M. A. Hussein et al., Application of the rock mass classification systems to pillar design in longwall mining forabu-tartur longwall phosphate mining conditions, pp. 2013 - 2020

\section{Table 1.}

Summary of empirical strength formulae for hard rock pillars where the pillar width and height is in meters.

\begin{tabular}{|l|l|l|l|}
\hline Pillar strength formulae $(\mathrm{MPa})$ & $\sigma_{\mathrm{c}}(\mathrm{MP})$ & Rock mass & Reference \\
\hline $133 \frac{W_{P}^{0.5}}{h^{0.75}}$ & 230 & Quartzites & {$[13]$} \\
\hline $65 \frac{W_{P}^{0.46}}{h^{0.66}}$ & 94 & Metasediments & {$[14]$} \\
\hline $35.4\left(0.778+0.222 \frac{W_{P}}{h}\right)$ & 100 & Limestone & {$[15]$} \\
\hline $0.42 \sigma_{c} \frac{W_{P}}{h}$ & - & Canadian Shield & {$[16]$} \\
\hline $74\left(0.778+0.222 \frac{W_{P}}{h}\right)$ & 240 & Limestone/Skarn & {$[17]$} \\
\hline $0.44 \sigma_{c}(0.68+0.52 k)$ & - & Hard rocks & {$[18]$} \\
\hline
\end{tabular}

\section{Pillar Stress}

The average pillar stress $\left(\sigma_{\mathrm{p}}\right)$, in regular layouts of square one chain pillars, can be estimated by the tributary area method as follows and as shown in $\operatorname{Fig}(1)[8,19]$.

$$
\sigma_{p}=\frac{\gamma\left[\left(W_{L}+W_{p}+2 \mathbf{B}\right) H-\frac{\left(W_{L}+\mathbf{B}\right)^{2}}{4 \tan \theta}\right]\left(W_{p}+\mathbf{B}\right)}{W_{p}^{2}}
$$

Where $\gamma$ is the specific weight of the overlying rocks, $H$ is the depth of cover, $W_{p}$ is the pillar width, $\mathrm{W}_{\mathrm{L}}$ is the panel width, $\theta$ is the abutment angle and $\mathrm{B}$ is the heading.

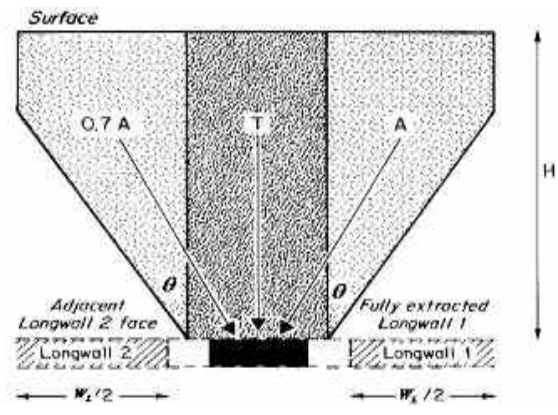

Key

A Side abutment

T Tributary

Fig. 1.Conceptual model of the side abutment load.[19]

\section{Pillar Strength Based On a New Failure Criterion}

Sheorey and et al, 1985 suggested a formula to estimate pillar strength $\sigma_{s}$ based on a new failure criterion represented by the following equation [20].

Journal of Engineering Sciences, Assiut University, Faculty of Engineering, Vol. 41, No. 5, September, 2013, E-mail address: jes@aun.edu.eg 
M. A. Hussein et al., Application of the rock mass classification systems to pillar design in longwall mining forabu-tartur longwall phosphate mining conditions, pp. $2012-2020$

$$
\sigma_{s}=0.66 k h^{-0.35}+5\left[\gamma H\left(1-e^{\left(-0.15 W_{p} /(25+0.1 H)\right)}\right)\right]^{0.8} \quad M P a
$$

Where:

$\mathrm{k}=\sigma_{\mathrm{cm}}=$ in-situ rock mass strength of the phosphate ore, $\mathrm{MPa}$

$\mathrm{h}=$ mining height, $\mathrm{m}$

Another equation is used Sheorey's failure criterion was chosen to determine $\sigma_{\mathrm{cm}}$ as a function of the RMR (Sheorey, 1997) [21,22,23]. This criterion is expressed by the following relationship.

$$
\sigma_{c m}=\sigma_{c i} e^{\frac{R M R-100}{25}}
$$

Where:

$\sigma_{c i}=$ compressive strength of intact rock, Mpa.

RMR $=$ Rock Mass Rating

\section{Geological and Mining Situation of Abu-Tartur Mines}

Longwall panels under investigation are located at Abu-Tartur plateau in the south-west of Egypt, in the Western desert. The plateau has a semi-oval shape and is exposed to the north -west direction. Its area comprises about $1200 \mathrm{Km}^{2}$. The phosphate layer is of $3.5 \mathrm{~m}$ average thickness and is located at a depth ranges from $50 \mathrm{~m}$ in the east to $260 \mathrm{~m}$ in west and average about of $200 \mathrm{~m}$. The phosphate layer is nearly horizontal with an angle of inclination $\left(0^{\circ}\right.$ to $\left.3^{\circ}\right)$ averaging about $1.5^{\circ}$. The immediate roof is composed of $17.5 \mathrm{~m}$ of papery clayey shales overlain by a layer of argillaceous sand of 6.6 to $16 \mathrm{~m}$ thickness. The stratigraphic column and rock properties are given in Table(2) $[4,24,25]$. Mine layout shows three ring galleries, the main and tailgates as well as rib pillars between the panels as shown in Fig. (2). the width of rib pillar equals $25 \mathrm{~m}$. The width of the pillars is determined on the basis of experimental mine observations. The maximum face length equals $150 \mathrm{~m}$ and panel extension is about $1000 \mathrm{~m}$ and the annual face advance is $760-800$ $\mathrm{m}[24]$.

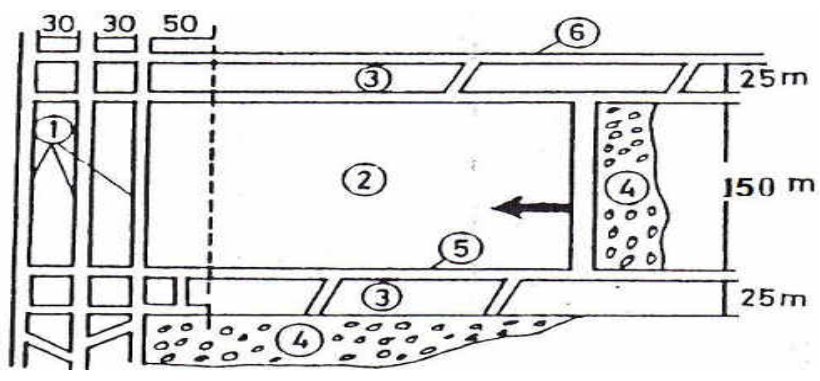

Fig. 2. layout of underground mine in Abu-Tartur site.

1-Ring galleries 2-panel 3-rib pillars 4 - goaf 5 -maingate 6 - tailgate

Journal of Engineering Sciences, Assiut University, Faculty of Engineering, Vol. 41, No. 5, September, 2013, E-mail address: jes@aun.edu.eg 
M. A. Hussein et al., Application of the rock mass classification systems to pillar design in longwall mining for abu-tartur longwall phosphate mining conditions, pp. $2013-2021$

Table 2.

Rock properties and stratigraphic column along Abu-Tartur plateau

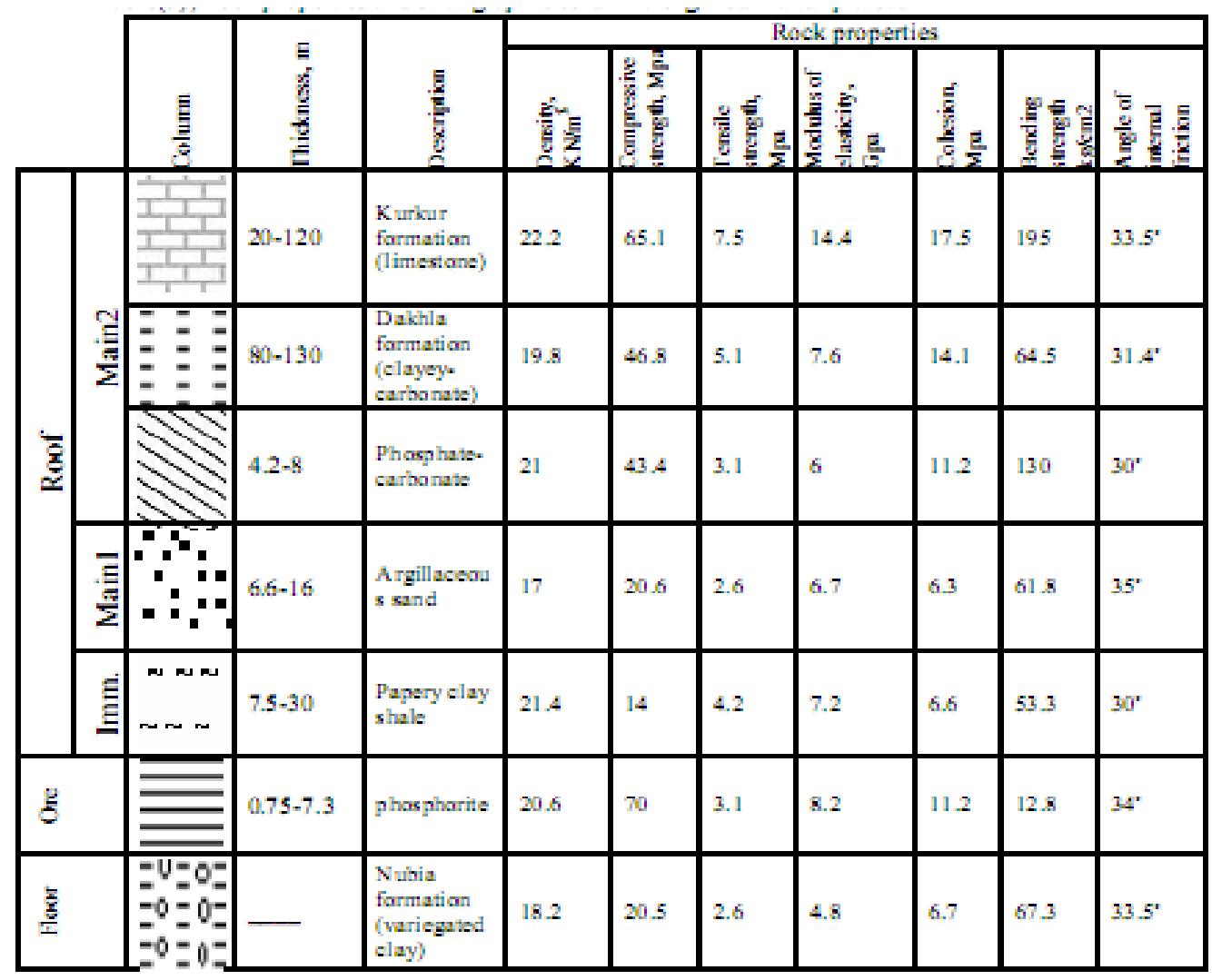

Pillar layout must be designed to decrease the possibility of pillar instability. It is difficult in practice to predict the exact pillar load and pillar strength. For determining the strength of pillar material, Salamon approach has been applied [24].

In Abu-Tartur area the longwall mining method is applied to exploit the phosphate ores. Proposed face lengths are 60,100 and $120 \mathrm{~m}$ with rib pillars of $25 \mathrm{~m}$ in width. Excessive convergence occurred in tailgate after extracting the panel which was supported by double channels face to face (square cross section) steel sets as posts with regular spacing about $75 \mathrm{~cm}$. Caps are double channels back to back (1 - beam cross section).[24,25]

To maintain the tailgates at good conditions to serve the next panel, supplemental supports must be installed thus increasing the cost of roof supports. The efficient design of rib pillars will improve the roof conditions in the main and tailgates. Consequently the cost of supports will decrease.[24]

The physical and mechanical properties of phosphate ore (pillar material), papery clays (Immediate roof) and the technical data in Abu-Tartur conditions are as follows: [24,25] Compressive strength of phosphate ore from laboratory tests $\sigma_{\mathrm{c}}=40 \mathrm{Mpa}$ and in-situ mass strength $\sigma_{c m}=15.760$ Mpa. [3].

Journal of Engineering Sciences, Assiut University, Faculty of Engineering, Vol. 41, No. 5, September, 2013, E-mail address: jes@aun.edu.eg 
M. A. Hussein et al., Application of the rock mass classification systems to pillar design in longwall mining for abu-tartur longwall phosphate mining conditions, pp. 2013 - 2021

Compressive strength of roof rock

Average depth below surface

Average specific weight of overburden rock

Mining height (pillar height)

Longwall face length

Abutment angle

Heading

Factor of safety

$$
\begin{aligned}
& \sigma \mathrm{r}=20.6 \mathrm{Mpa} . \\
& \mathrm{H}=200 \mathrm{~m} \\
& \gamma=25 \mathrm{KN} / \mathrm{m}^{3} \\
& \mathrm{~h}=3.5 \mathrm{~m} \\
& \mathrm{~W}_{\mathrm{L}}=100 \mathrm{~m} \\
& \theta=30^{\circ} \\
& \mathrm{B}=3 \mathrm{~m} \\
& \text { F.S }=2
\end{aligned}
$$

\section{Calculation of Dimension of Pillar By Rock Mass Classification Systems}

$$
\begin{gathered}
F . S=\frac{\sigma_{s}}{\sigma_{p}}=2 \\
F . S=\frac{\left(0.66 k h^{-0.35}+5\left[\gamma H\left(1-e^{-1.5 w_{p} /(25+0.1 H)}\right)\right]^{0.8}\right) W_{p}^{2}}{\gamma\left[\left(W_{L}+W_{p}+2 B\right) H-\frac{\left(W_{L}+B\right)^{2}}{4 \tan \theta}\right]\left(W_{p}+B\right)}=2 \\
\left.2=\frac{\left(0.66 \times 15.76 \times 3.5^{-0.35}+5\left[0.025 \times 200\left(1-e^{-1.5 w_{p} /(25+20)}\right)\right]^{0.8}\right) W_{p}^{2}}{(100+3)^{2}}\right]\left(W_{p}+3\right) \\
\quad 0.025\left[\left(100+W_{p}+2 \times 3\right) 200-\frac{(10030]}{4 \tan 30}\right] \\
2490.923 W_{p}^{-2}+860.308 W_{p}^{-1}-18.119\left(1-e^{-1.5 w_{p} / 45}\right)^{0.8}-3.291=0 \\
\therefore W_{p}=49.1 m \approx 49 m
\end{gathered}
$$

\section{Pillar Strength by RMR}

$$
\sigma_{c m}=\sigma_{c i} e^{\frac{R M R-100}{25}}
$$

GSI value for phosphate ore is determine in work [3,4], GSI = 55 and by correlation between RMR and GSI from this relationship [5] as flows:

$$
\begin{aligned}
& \mathrm{RMR}=\mathrm{GSI}+5 \quad \therefore \mathrm{RMR}=55+5=60 \\
& \text { Pillar strength } \quad \sigma_{s}=\frac{\sigma_{c m} \times W_{P}^{0.46}}{h^{0.66}} \\
& \sigma_{s}=\frac{\sigma_{c i} \times W_{P}^{0.46}}{h^{0.66}} e^{\frac{R M R-100}{25}}
\end{aligned}
$$

Pillar stress for square one raw chain pillar 
M. A. Hussein et al., Application of the rock mass classification systems to pillar design in longwall mining for abu-tartur longwall phosphate mining conditions, pp. 2013 - 2021

$$
\begin{aligned}
& \sigma_{p}=\frac{\gamma\left[\left(W_{L}+W_{p}+2 \mathbf{B}\right) H-\frac{\left(W_{L}+\mathbf{B}\right)^{2}}{4 \tan \beta}\right]\left(W_{p}+\mathbf{B}\right)}{W_{p}^{2}} \\
& F . S=\frac{\sigma_{s}}{\sigma_{p}}=2 \\
& 2=\frac{\sigma_{c m} \times W_{P}^{0.46} \times W_{p}^{2}}{\gamma\left[\left(W_{L}+W_{p}+2 \mathbf{B}\right) H-\frac{\left(W_{L}+\mathbf{B}\right)^{2}}{4 \tan \beta}\right]\left(W_{p}+\mathbf{B}\right) h^{0.66}} \\
& 2=\frac{\sigma_{c i} e^{\frac{R M R-100}{25} \times W_{P}^{2.46}}}{0.025\left[\left(100+W_{p}+6\right) 200-\frac{(100+3)^{2}}{4 \tan 30}\right]\left(W_{p}+3\right) \times 3.5^{0.66}} \\
& 70.654 W_{P}^{2.46}=21200 W_{P}+200 W_{P}^{2}-4593.832 W_{P}+600 W_{p}+49818.505 \\
& 70.654 W_{P}^{2.46}-200 W_{P}^{2}-17206.168 W_{P}-49818.505=0 \\
& \therefore W_{p}=64.3 m \approx 64 m
\end{aligned}
$$

\section{Conclusions}

From this study, the following conclusions can be drawn:

1) Efficient extraction of ores by longwall mining cannot be achieved without taking into consideration the stability of the workings. If a pillar layout is perfectly stable then uncontrolled pillar collapse and excessive convergence in the roof of tailgates may not be occurred.

2) The value of RMR is determined by correlation with GSI value and equal to 60

3) The pillar widths calculated by rock mass classifications are $49 \mathrm{~m}$ and $64 \mathrm{~m}$ at a factor of safety $=2$ and panel width $100 \mathrm{~m}$ with extraction ratios of 70 and $64 \%$ respectively.

\section{References}

[1] Porter, I. Analysis of Rock Mass Classification Systems for Crown Pillar Design. AUSIMM Student Conference - Pathway to Industry, 1994.

[2] Mark, C. Empirical Methods for Coal Pillar Design. National Institute for Occupational Safety and Health, U.S.A, June 1999.

[3] Hussein, A.L.,Imbaby,S.S. and Ibrahim, A.R. Panel Width Affected By Rock mass Classifications ( Abu-Tartur Phosphate Mines). JES,Vol.41,No.(3),May,2013.

[4] Hussein, A.L., Ibrahim, A.R. and Imbaby,S.S. Load Calculations And Selection Of The Powered Supports Based On Rock Mass Classification And Other Formulae For Abu-Tartur Longwall Phosphate Mining Conditions. Accepted and under publishing in JES,Vol.41,No.(4),Jul,2013.

[5] Martin, C.D. and Maybee, W.G. The Strength of Hard Rock Pillars. Int. Jnl. Rock Mechanics \& Min. Sci.37:1239-1246. , 2000.

Journal of Engineering Sciences, Assiut University, Faculty of Engineering, Vol. 41, No. 5, September, 2013, E-mail address: jes@aun.edu.eg 
M. A. Hussein et al., Application of the rock mass classification systems to pillar design in longwall mining for abu-tartur longwall phosphate mining conditions, pp. 2013 - 2021

[6] Trueman, R., Thin, I.G.T. and Tyler, D.B. Rock Mass Classification As An Aid To Estimating The Strength Of Coal Pillars. 11th Int. Con. on Ground Control in Mining, the University of Wollongong, N.S.W, July, 1992.

[7] Brady, B.H.G. and Brown, E.T. Rock Mechanics for Underground Mining. George Allen and Unwin, London, 527 pp, 1985.

[8]Gabriel, E., Dennis, D. and John, E. Pillar Strength and Design Methodology for Stone Mines. 27th International Conference on Ground Control in Mining

[9] Mark, C. Empirical Methods for Coal Pillar Design. Proceedings of the Second International Workshop on Coal Pillar Mechanics and Design, National Institute for Occupational Safety and Health, IC 9448, pp. 145-154. , 1999.

[10] Lunder, P.J. and Pakalnis, R. Determining the Strength of Hard Rock Mine Pillars. Bull. Can. Inst. Min. Metall. 90:51-55. , 1997.

[11] Hustrulid, W.A. A Review of Coal Pillar Strength Formulas. Rock Mechanics and Rock Engineering 8(2), pp.115-145, 1976.

[12] Laubscher, D.H. A Geomechanics Classification System For The Rating Of Rock Mass In Mine Design. J. S. Atr. Inst. Min. Metal/, vol. 90, no. 10, pp. 257-273. Qct. 1990.

[13] Hedley, D.G.F. and Grant, F. Stope-and-pillar design for the Elliot Lake Uranium Mines. Bull Can Inst Min Metall;65:37244, 1972.

[14] Von Kimmelmann, M.R., Hyde, B. and Madgwick, R.J. The Use Of Computer Applications At BCL Limited In Planning Pillar Extraction And Design Of Mining Layouts. In: Brown ET, Hudson JA, editors. Proceedings of ISRM Symposium: Design and Performance of Underground Excavations. London: British Geotechnical Society, p.53263, 1984.

[15] Krauland, N. and Soder, P.E. Determining Pillar Strength from Pillar Failure Observations. Eng Min J.;8:34240, 1987.

[16] Potvin,Y.,Hudyma, M.R. and Miller, H.D.S..Design Guide Lines for Open Stope Support. Bull Can Min Metall;82:53262, 1989.

[17] Sjoberg, J. Failure Modes And Pillar Behavior In The Zinkgruvan Mine. In: Tillerson J.A. and Wawersik W.R., editors. Proceedings of $33^{\text {rd }}$ U.S. Rock Mechanics Symposium, SanteFe. Rotterdam:A.A. Balkema, p.49:12500, 1992.

[18] Lunder, P.J. and Pakalnis, R. Determination Of The Strength Of Hard-Rock Mine Pillars. BullCan Inst Min Metall;90:5125. 1997.

[19] Colwell, M., Frith R. and Mark C. Analysis Of Longwall Tailgate Serviceability (ALTS): A Chain Pillar Design Methodology For Australian Conditions. National Institute for Occupational Safety and Health, U.S.A. June 1999.

[20] Sheorey,P.R. , Bordia,S. K. and Singh,B. Pillar Strength Approaches Based On A New Failure Criterion For Coal Seams. International Journal of Mining and Geological Engineering, 4, 273-290, 1986.

[21] Sheorey,P.R. Empirical Rock Failure Criteria. A. A. Balkema Publ., Rotterdam, 1997.

[22] Gonzalez-Nicieza,C., Alvarez-Fernandez,M.I. and Alvarez-Vigil, A.E. A Comparative Analysis of Pillar Design Methods and its Application to Marble Mines. Rock Mech. Rock Engng.(5),421-444,2006.

[23] Kushwaha, A., Singh, S.K. and Sinha, A. Empirical Approach For Designing Of Support System In Mechanized Coal Pillar Mining. International Journal of Rock Mechanics \& Mining Sciences 47,1063-1078, 2010.

[24] Gomma, W.A. and Imbaby,S.S. Application Of The Cavability Concept To Pillar Design In Longwall Mining (Abu-Tartur Mining Conditions). $16^{\text {th }}$ Mining Congress of Turkey, ISBN 975-395-310-0, 1999.

Journal of Engineering Sciences, Assiut University, Faculty of Engineering, Vol. 41, No. 5, September, 2013, E-mail address: jes@aun.edu.eg 
M. A. Hussein et al., Application of the rock mass classification systems to pillar design in longwall mining for abu-tartur longwall phosphate mining conditions, pp. 2013 - 2021

[25] Executive Summary on Geological, Geomechanical and Geotechnical Characteristics of Abu Tartur Deposits. Geological and Mining research department Abu Tartur Phosphate project, July 1997.

\section{تطبيق أنظمة تصنيفات الكتل الصخرية في تصميم أعمدة

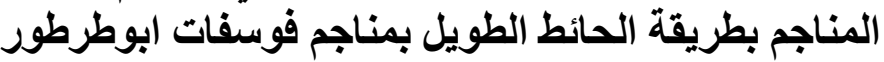

الملخص العربي

يتم تصميم الأعمدة في المناجم لضمان آمان منطقة المنجم بالكامل او للتدعيم المحلي مثل واجهة الحش و وإن

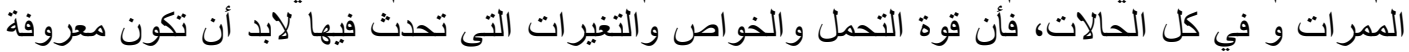

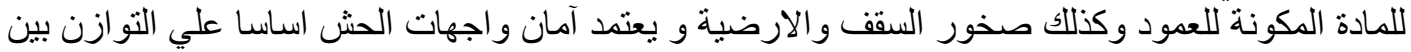

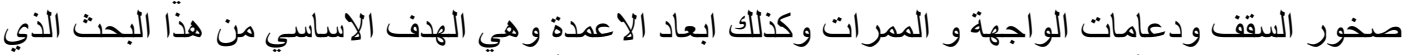

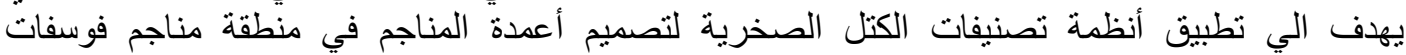

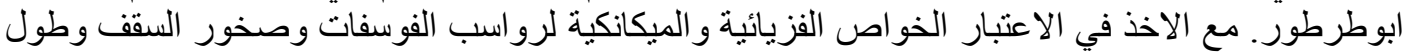

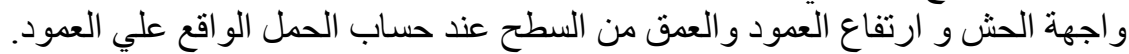

و قد تم استخدام طريقتان من انظمة تصنيفات الكتل الصخرية هما (GSI) and Rock Mass Rating (RMR) systems ابعاد العمود و قد تم تعبين قيم GSI لصخور السقف ورواسب الخام من الخواص الجيولوجية و كذلك

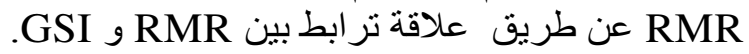

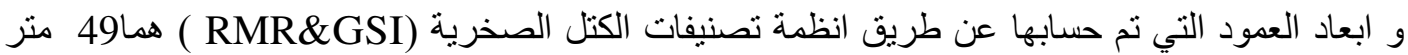
و64 متر بعامل آمان قدره 2 مع طول واجهة حش مقدار ها 100 متر بنسبة استخراج 70 و 64 \% ) علي الترنيب. و البينات التي استخدمت في الحسابات تم الحصول عليها من التقارير الجيولوجية لدي الثركة ومن

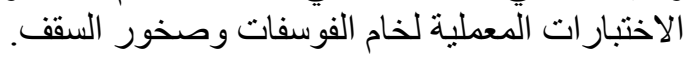

Journal of Engineering Sciences, Assiut University, Faculty of Engineering, Vol. 41, No. 5, September, 2013, E-mail address: jes@aun.edu.eg 